\title{
MENGUKUR ETOS KERJA MUSLIM DI FAKULTAS EKONOMI DAN BISNIS ISLAM IAIN PADANGSIDIMPUAN
}

\author{
Rodame Monitorir Napitupulu \\ Institut Agama Islam Negeri Padangsidimpuan \\ Jalan T. Rizal Nurdin Km. 4,5 Sihitang, Padangsidimpuan \\ Email: rodamenapitupulu@iain-padangsidimpuan.ac.id
}

\begin{abstract}
Abstrak,
Indonesia juga adalah Negara dengan penduduk muslim tertinggi di dunia. Hal tersebut menjadikan Indonesia dengan jumlah usia kerja produktif tinggi berpotensi menjadi sumber dari sumber daya manusia yang memiliki etos kerja yang baik. Dalam Islam sendiri, sebenarnya sudah ada etos kerja muslim yang dapat dijadikan kekuatan dalam meningkatkan kualitas SDM. Sebagai sebuah institusi pendidikan, tenaga administrasi dan tenaga pendidik (dosen) di Fakultas Ekonomi dan Bisnis Islam IAIN Padangsidimpuan juga dituntut untuk memberikan contoh dengan menunjukkan etos kerja muslim yang tinggi sehingga visi dan misi dapat tercapai. Pengukuran etos kerja muslim di Fakultas Ekonomi dan Bisnis Islam IAIN Padangsidimpuan perlu dilakukan untuk mengetahui sudah sejauh mana etos kerja muslim melekat dalam diri masing-masing pegawai. Dengan pendekatan kualitatif deskriptif dimana jumlah responden sebanyak 16 orang yang dipilih dengan teknik purposive sampling. Hasil penelitian menunjukkan bahwa mayoritas pegawai di Fakultas Ekonomi dan Bisnis Islam IAIN Padangsidimpuan sudah memiliki etos kerja muslim yang baik terutama ciri al-shalah (baik dan manfaat), al-itqan (kemantapan dan perfectness), tanafus dan ta'awun (berkompetisi dan tolong-menolong) dan mencermati nilai waktu.
\end{abstract}

Kata Kunci: Etos Kerja Muslim, Sumber Daya Manusia, IAIN Padangsidimpuan

\begin{abstract}
,
Indonesia now and some years later will enter the demography bonus. It means that the number of people in productive age will increase too which will also need the enhancement of quality human resources. Indonesia now become the highest Muslim population in the world. It becomes Indonesia have a great potency to be a source of human resources with a high work ethic. In Islam, there is also a Muslim work ethic in organization. Muslim work ethic can be empower human resources so that it can win the competition of work and business. As one of the education institution, the staff and lecturer in Faculty of Business and Economic Islamic, IAIN Padangsidimpuan should become a role model that have a high Muslim work ethic. The purpose of this research is to measure the Muslim work ethic in Faculty of Business and Economic Islamic, IAIN Padangsidimpuan. It uses qualitative descriptive approach with 16 respondent. The result shows that Muslim work ethic has run well especially character Al-Shalah, Al-Itqan, Tanafus and Ta'awun, Use of Time. Only one character that still low, namely Al-Mujahadah.
\end{abstract}

Keywords: Muslim Work Ethic, Human Resources, IAIN Padangsidimpuan 


\section{PENDAHULUAN}

Kehidupan berorganisasi atau bekerja dalam berbagai bidang saat ini sulit dipisahkan dari etos kerja. Dapat dikatakan bahwa salah satu penentu keberhasilan seseorang dalam kehiduapn beroganisasi dan bekerja adalah etos kerja. Jika seseorang memiliki etos kerja yang baik tentu saja akan mendukung seluruh aspek dalam kehidupannya. Di tengah-tengah persaingan sumber daya manusia (SDM) saat ini, etos kerja dapat menjadi keunggulan seseorang agar semakin meningkat reputasi, kredibilitas dan nama baiknya. Persaingan SDM bukan hanya terjadi di Negara-negara maju seperti Jepang, Cina dan Amerika tetapi juga terjadi di Indonesia. Setiap perusahaan atau organisasi berlomba-lomba menciptakan budaya organisasi dan etika perusahaan demi mencapai visi dan misi perusahaan/organisasi.

Demikian juga halnya, dalam kehidupan beragama. Pada dasarnya Islam sudah memberikan tuntunan yang sangat baik dalam berorganisasi dan bekerja. Hanya saja, banyak faktor dari luar diri (eksternal) maupun dari dalam diri (internal) yang pada akhirnya menghambat terlaksananya apa yang telah diajarkan Alquran dan Hadist pada manusia. Faktor dari luar dapat berupa: teknologi, masuknya budaya asing, kecintaan berlebihan pada sesuatu sedangkan faktor dari dalam dapat berupa: kurangnya motivasi, kurangnya semangat, kurangnya rasa memiliki dan lain sebagainya. Tentu saja hal tersebut menyebabkan terjadinya perubahan perilaku berorganisasi dan bekerja di masyarakat muslim di Indonesia.

Dengan jumlah penduduk muslim yang tinggi di Indonesia, maka sudah seharusnya masyarakat muslim di Indonesia menjadi contoh atau panutan dalam berorganisasi dan bekerja. Perbandingan jumlah penduduk muslim di dunia dapat dilihat pada Gambar 1.

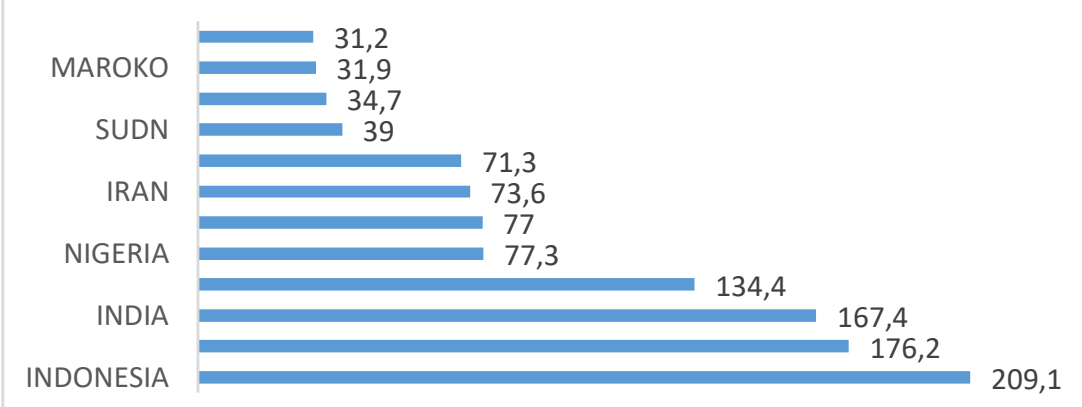

Sumber: https://www.thoughtco.com/worlds-muslim-population-2004480, diakses 06 September 2018 pukul 17.04 WIB

Gambar 1. Negara dengan Jumlah Penduduk Muslim Tertinggi di Dunia per 2017 (Dalam Jutaan) 
Sementara itu tingkat persaingan SDM di dunia juga mengalami peningkatan terutama karena sudah memasuki perdagangan bebas. Semua Negara kini berlomba-lomba meningkatkan kualitas SDM demi memenangkan persaingan dalam berbisnis. Keberhasilan sebuah bisnis tidak terlepas dari kualitas SDM-nya. Itulah sebabnya, Indonesia dengan mayoritas muslim tertinggi memiliki potensi untuk menjadi sumber SDM berkualitas dengan etos kerja muslim yang melekat kuat dalam dirinya.

Jumlah usia produktif di Indonesia menurut umur dan jenis kelamin dapat dilihat pada Gambar 2. berikut ini:



Sumber: https://databoks.katadata.co.id/datapublish/2018/05/18/2018-jumlah-pendudukindonesia-mencapai-265-juta-jiwa, diakses 29 Agustus 2018 pukul 17.16 WIB

\section{Gambar 2. Jumlah Penduduk Indonesia Menurut Kelompok Umur (2018)}

Berdasarkan Gambar 2, maka dapat dlihat bahwa Indonesia saat ini dan beberapa tahun ke depan akan berada pada puncak tertinggi usia produktifnya. Inilah yang disebut dengan istilah bonus demografi. Oleh karena itu, kualitas SDM menjadi sesuatu yang sangat penting untuk diperhatikan semua pihak untuk dapat terus bersaing dan memenangkan persaingan terutama dalam dunia bisnis juga dunia pendidikan.

\section{TINJAUAN TEORITIK}

\section{Konsep Manajemen Syariah}

Pada dasarnya dalam ajaran Islam, segala sesuatu tidak boleh dikerjakan dengan asalasalan justru sebaliknya harus rapi, benar, jelas dan terarah. Rasullah saw. bersabda dalam sebuah hadist yang diriwayatkan Imam Thabrani, sesungguhnya Allah sangat mencintai orang yang jika melakukan sesuatu pekerjaan, dilakukan denga Itqan (tepat, terarah, jelas dan tuntas) 
(Al-Hasyimi dalam Didin dan Tanjung, 2003). Hal tersebut mencerminkan bahwa dalam ajaran Islam sudah tercakup juga konsep manajemen syariah.

Jika dikaitkan dengan definisi manajemen itu sendiri, dimana manajemen yaitu suatu proses atau kerangka kerja yang melibatkan bimbingan atau pengarahan suatu kelompok orangorang ke arah tujuan-tujuan organisasional atau maksud-maksud yang nyata (Terry, 2005). Menurut (Schein, 2008), manajemen merupakan profesi dimana profesi tersebut menuntut untuk bekerja dengan profesional. Dari kedua pandapat para ahli tersebut, maka dapat dikatakan bahwa manajemen adalah proses untuk mencapai tujuan yang dilakukan dengan cara profesional. Islam sudah lebih dahulu mengajarkan hal tersebut seperti yang disebutkan dalam HR Thabrani.

Menurut (Didin dan Tanjung, 2003), dalam konsep manajemen syariah setidaknya terdapat 3 hal yang harus diperhatikan dalam bekerja, yaitu:

1. Perilaku

Perilaku yang dimaksud adalah yang berkaitan dengan nilai-nilai keimanan dan ketauhidan.

2. Struktur Organisasi

Terdapat struktur dan stratifikasi dimana keberadaan struktur dengan posisi/jabatan yang berbeda-beda yang digunakan bukan untuk kepentingan sendiri adalah sunnatullah.

3. Sistem

sistem yang syariah yang disusun harus menjadikan perilaku pelakunya berjalan dengan baik dimana sumber dari segala aturan kehidupan manusia yang ada pada sistem harus berasal dari Alquran dan Sunnah Rasul.

\section{Etos Kerja Muslim}

Menurut (Didin dan Tanjung, 2003), etos kerja muslim dalam organisasi juga memiliki ciri-ciri, yang meliputi:

1. Al-Shalah atau baik dan manfaat

2. Al-Itqan atau kemantapan dan perfectness

3. Al-Ikhsan atau melakukan yang terbaik dan lebih baik lagi

4. Al-Mujahadah atau kerja keras dan optimal

5. Tanafus dan Ta'awun atau berkompetisi dan tolong-menolong

6. Mencermati nilai waktu

Selanjutnya ciri etos kerja muslim dalam organisasi digambarkan seperti pada Gambar 3 .

Al-Shalah 


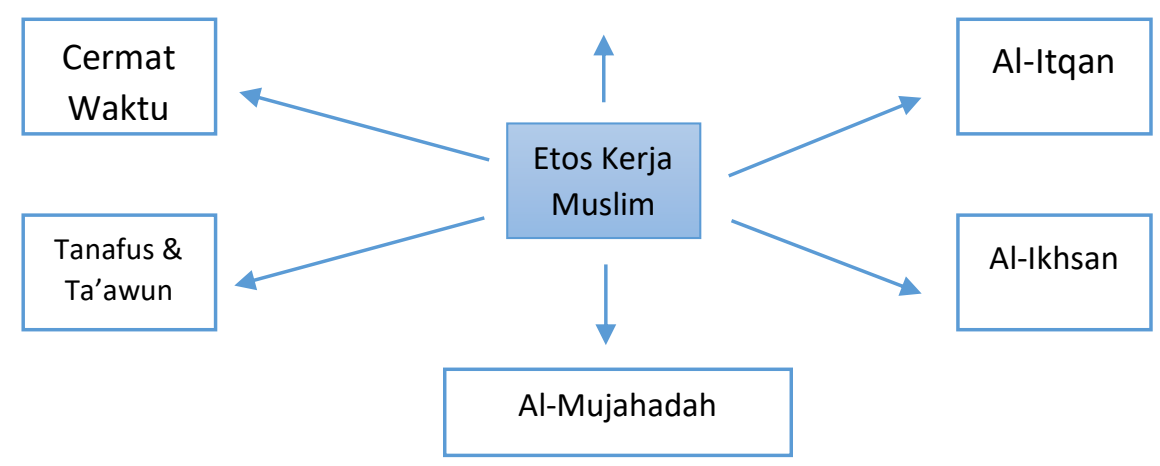

Sumber: Didin dan Tanjung (2003)

Gambar 3. Etos Kerja Muslim

\section{METODE PENELITIAN}

\section{Jenis Penelitian}

Penelitian ini adalah penelitian kualitatif. Jenis penelitian kualitatif ini menyarankan suatu pendekatan a priori yang didasarkan pada asumsi filosofis (pendekatan naturalistis interpretif) (Emzir, 2014).

\section{Pendekatan Penelitian}

Penelitian ini menggunakan pendekatan kualitatif yaitu penelitian yang dilakukan dengan mengamati fenomena disekitarnya dan dianalisis dengan menggunakan logika ilmiah. Penelitian ini juga menggunakan metode deskriptif yaitu penelitian yang bertujuan menggambarkan keadaan sebenarnya di lapangan secara murni, apa adanya dan holistik sesuai konteks penelitian. Hal ini dinyatakan oleh Gay dan Airasian bahwa "descriptive study determines and describes the things are"(Gay and Airasian, 200o). Selain itu ditambahkan juga bahwa penelitian deskriptif dapat juga berupa penilaian, tingkahlaku, opini, kesukaan, demografi suatu tempat, praktik dan prosedur.

\section{Teknik Penetapan Responden}

Penelitian ini menggunakan dua jenis data yaitu: data primer dan data sekunder. Data primer diperoleh hasil kuesioner yang dibagikan kepada responden secara langsung. Sampel dalam penelitian sekaligus sebagai responden penelitian dengan purposive sampling dimana kriterianya adalah mereka yang bekerja sebagai tenaga pendidik (dosen) dan tenaga administrasi di Fakultas Ekonomi dan Bisnis Islam IAIN Padangsidimpuan minimal 1 tahun. Jumlah responden 16 orang (3 orang tenaga administrasi dan 13 orang tenaga pendidik (dosen) yang dianggap sudah mewakili populasi. Populasi dalam penelitian ini berjumlah 28 orang terdiri dari 6 orang tenaga 
administrasi dan 22 orang tenaga pendidik (dosen). Sedangkan data sekunder diperoleh dari buku, jurnal, data dari instansi pemerintah atau swasta yang memiliki hubungan dengan penelitian. Kuesioner pada penelitian ini berupa angket tertutup atau terstruktur yang disusun dengan menyediakan pilihan jawaban sehingga responden hanya memberikan tanda pada jawaban yang dipilih (Maman dan Muhidin, 2009).

\section{Teknik Analisis Data}

Teknik analisis data pada penelitian ini dilakukan dengan statistik deskriptif. Statistik deskriptif adalah metode statistik yang berusaha menjelaskan atau menggambarkan berbagai karakteristik data (Muhammad, 2008). Seperti berapa rata-ratanya, seberapa jauh data-data bervariasi, berapa standar deviasinya, nilai maksimum dan minimum data. Analisis deskriptif mengacu pada transformasi dari data-data mentah ke dalam suatu bentuk yang mudah dimengerti dan diterjemahkan. Pendeskripsian penilaian dari responden merupakan ciri khas dari bentuk pertama analisis. Termasuk didalamnya ada perhitungan rata-rata, distribusi frekuensi dan distribusi persentase yang merupakan bentuk paling umum dari peringkasan data (Dermawan, 2003). Kemudian pembahasan hasil analisis data dilakukan dengan membandingkannya dengan teori, buku teks, jurnal dan hasil penelitian terdahulu dan berbagai informasi terkini lainnya yang terkait dengan etos kerja muslim.

\section{HASIL DAN PEMBAHASAN}

Hasil penelitian ini dibagi menjadi 2 pemaparan, pertama adalah pemaparan karakteristik responden dan yang kedua adalah pemaparan hasil pengukuran etos kerja muslim di Fakultas Ekonomi dan Bisnis Islam.

\section{Karakteristik Responden Penelitian}

Berdasarkan hasil penelitian diketahui bahwa sebanyak 12 orang berjenis kelamin perempuan sedangkan sisanya 5 orang berjenis kelamin laki-laki. Selengkapnya terdapat pada Gambar 4 .

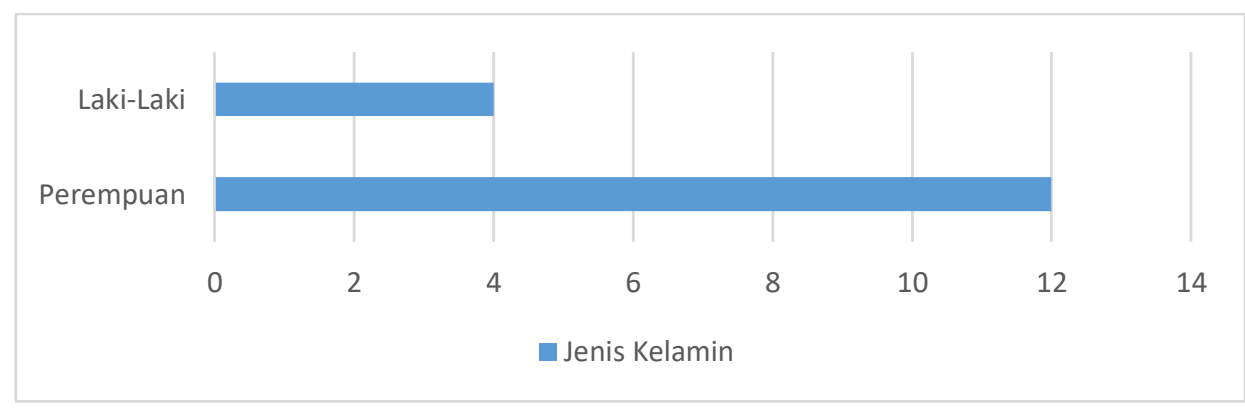




\section{Gambar 4. Jenis Kelamin Responden}

Berdasarkan Gambar 5, diketahui sebanyak 13 orang bekerja sebagai tenaga pendidik (dosen) dan sisanya sebanyak 3 orang bekerja sebagai tenaga administrasi. Selengkapnya dapat dilihat pada Gambar 5 .



\section{Gambar 5. Bidang Kerja Responden}

Mayoritas responden berusia pada > 30 tahun sebanyak 10 orang sedangkan mereka yang berusia 25-30 tahun sebanyak 6 orang. Selengkapnya, dapat dilihat pada Gambar 6.

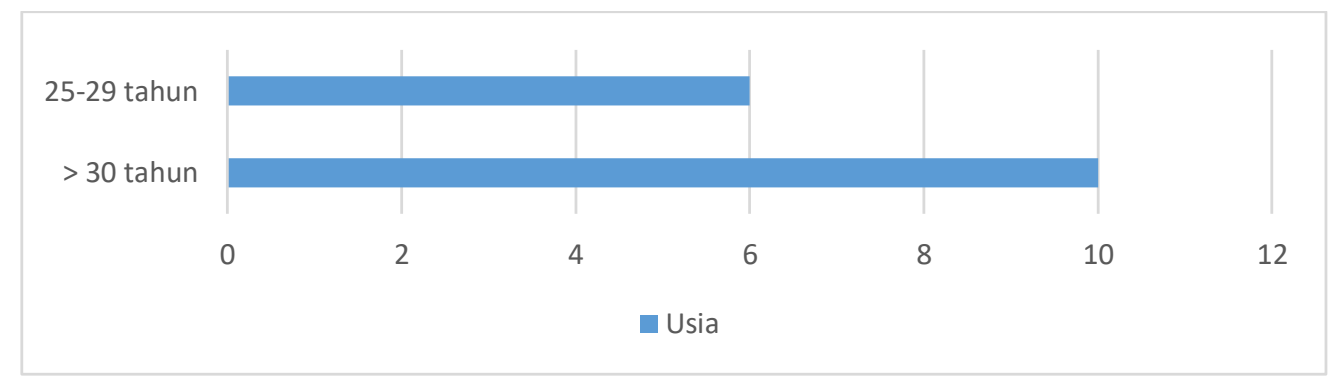

\section{Gambar 6. Rentang Usia Responden}

Sementara itu, diketahui bahwa mayoritas responden telah bekerja selama 4 tahun sebanyak 7 orang sedangkan mereka yang bekerja selama 7 tahun, sedangkan yang bekerja terlama adalah 25 tahun yaitu sebanyak 1 orang. Selengkapnya, dapat dilihat pada Gambar 7.

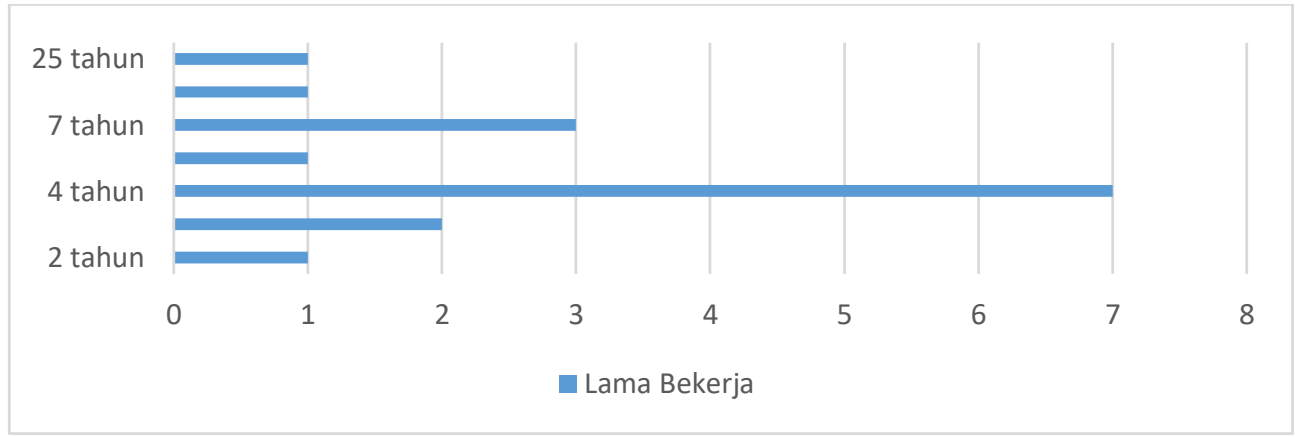




\section{Gambar 7. Lama Bekerja}

\section{Hasil Pengukuran Etos Kerja Muslim}

Berdasarkan hasil pengukuran terhadap etos kerja muslim yang dilakukan pada tenaga pendidik dan administrasi di Fakultas Ekonomi dan Bisnis Islam. Dimana jumlah total responden sebanyak 17 orang dengan karakteristik yang telah dipaparkan sebelumnya. Namun pada hasil kali ini yang difokuskan adalah pada 6 instrumen etos kerja muslim sesuai teori Hafidhuddin dan Tanjung pada buku yang berjudul Manajemen Syariah dalam Praktik Al-Shalah, Al-Itqan, AlIhsan, Al-Mujahadah, Tanafus dan Ta'awun dan Mencermati Nilai Waktu.

\section{Menilai Etos Kerja Muslim Al-Shalah}

Pada pertanyaan kesediaan menawarkan bantuan pada mahasiswa dan rekan yang kesulitan ketika melaksanakan pekerjaan ini, sebanyak $65 \%$ responden setuju akan hal tersebut dan 29 \% sangat setuju. Hal ini sudah menunjukkan hal yang positif karena mayoritas bersedia menawarkan bantuan pada mahasiswa dan rekan yang kesulitan. Berarti etos kerja muslim alshalah sudah ada dalam diri namun belum menunjukkan nilai maksimal.



\section{Gambar 8. Kesediaan Menawarkan Bantuan}

Sementara itu, untuk pertanyaan senang memberikan solusi kepada rekan maupun mahasiswa itu dinilai positif oleh responden dimana sebanyak $46 \%$ responden senang ketika mampu memberikan solusi kepada rekan dan mahasiswa. Selanjutnya sebanyak $41 \%$ responden sangat setuju dengan pertanyaan tersebut (lihat Gambar 9). 


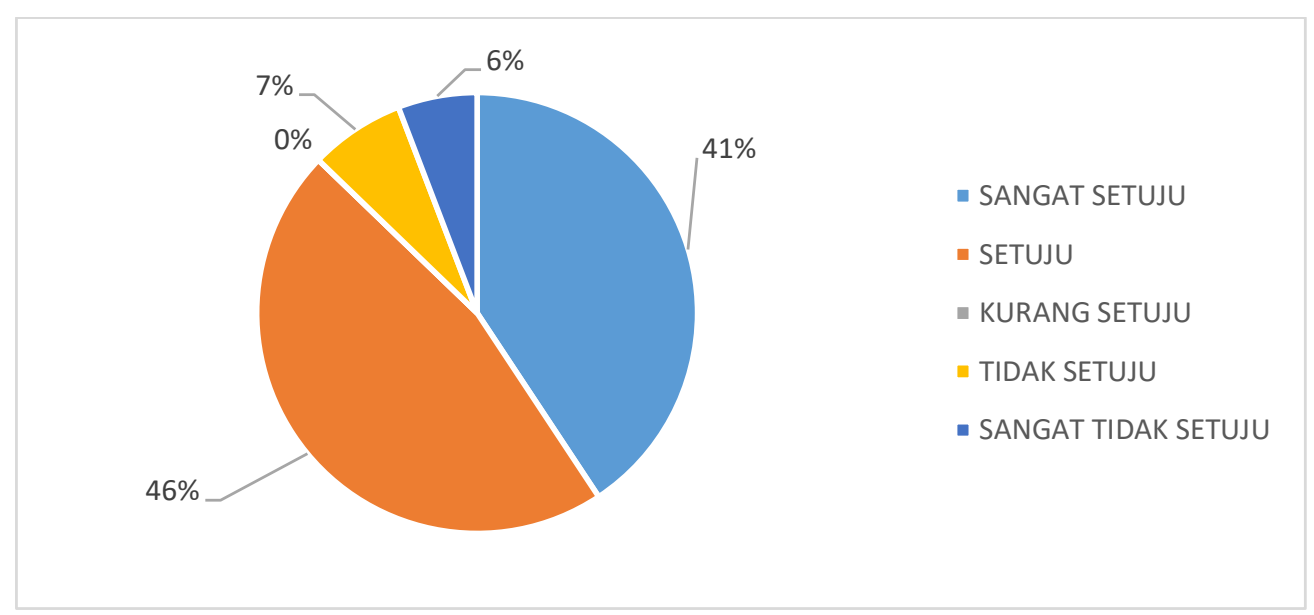

\section{Gambar 9. Senang Memberi Solusi}

\section{Mengukur Etos Kerja Muslim Al-Itqan}

Pada pertanyaan komitmen, sebanyak 81 \% setuju bahwa mereka selalu bekerja dengan penuh komitmen. Sisanya $13 \%$ sangat setuju dan hanya $6 \%$ yang tidak setuju dengan pertanyan tersebut (Gambar 10). Hal ini menunjukkan bahwa mayoritas tenaga pendidik dan administrasi bekerja penuh dengan komitmen.

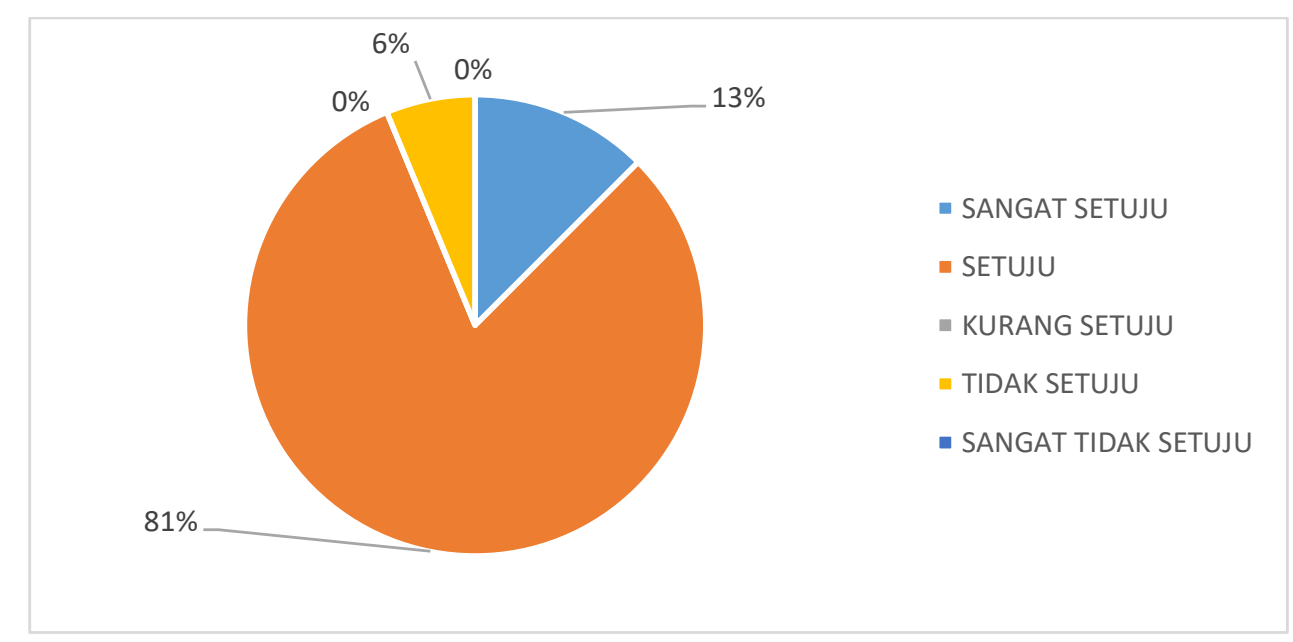

Gambar 10. Komitmen

Sementara itu, berdasarkan Gambar 11, untuk pertanyaan berusaha melakukan yang terbaik ketika berkerja, sebanyak $63 \%$ orang sangat setuju dan $31 \%$ orang setuju dengan pertanyaan tersebut. Hanya $6 \%$ yang tidak setuju dengan pertanyaan tersebut. 


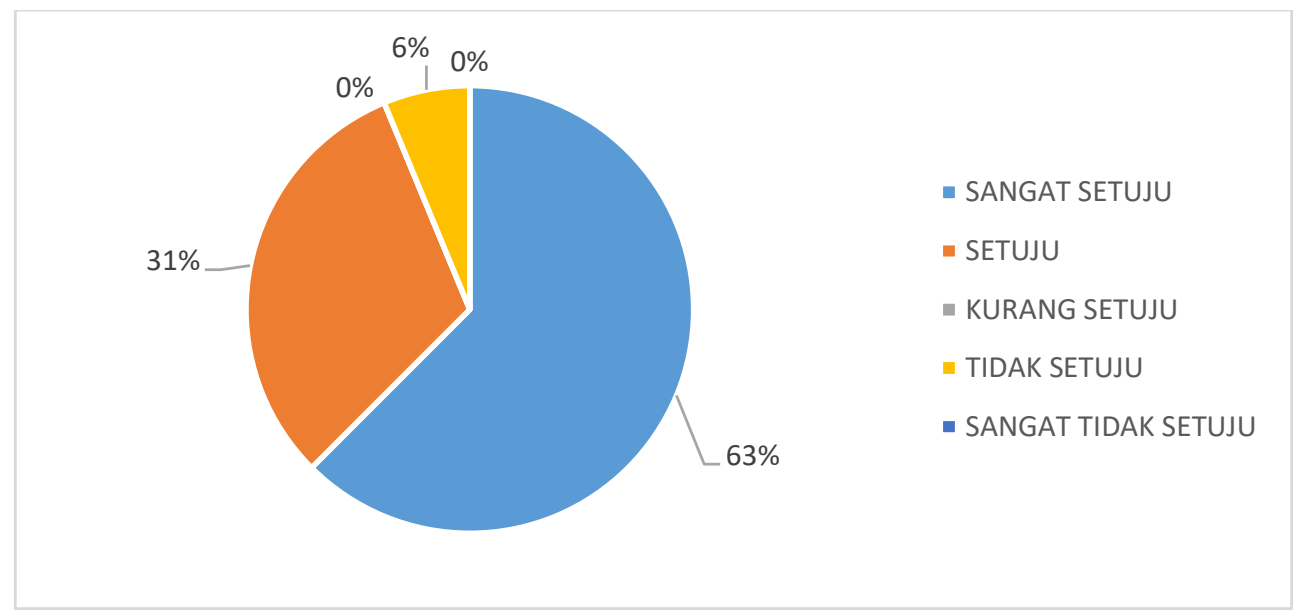

Gambar 11. Melakukan yang Terbaik

\section{Mengukur Etos Kerja Muslim Al-Ihsan}

Pada pertanyaan bekerja hanya mengikuti standar yang ditetapkan, sebanyak $59 \%$ setuju bahwa mereka bekerja hanya mengikuti standar yang ditetapkan. Hal tersebut bermakna bahwa sebagian besar masih belum mau bekerja di atas standar atau bekerja dengan nilai lebih dari ekspektasi. Sedangkan sisanya sebanyak 23 \% kurang setuju dengan pertanyan tersebut (Gambar 12). Dalam hal ini, ternyata ada juga responden yang ingin bekerja lebih dari standar yang ditetapkan meskipun hanya $23 \%$.

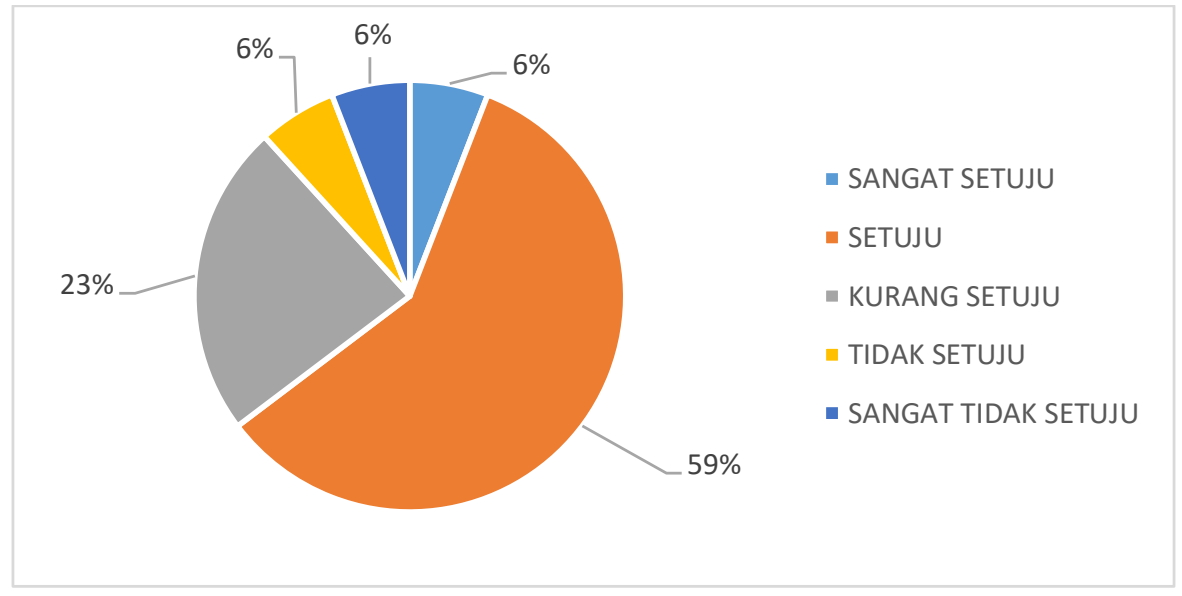

\section{Gambar 12. Bekerja Hanya Mengikuti Standar}

Selanjutnya pada pertanyaan lainnya yang mengukur etos kerja al-ihsan yakni pada pertanyaan ingin menjadi yang terbaik, sebanyak $53 \%$ responden setuju bahwa mereka ingin menjadi yang terbaik dan sebanyak 35 \% sangat setuju akan pertanyaan tersebut. Hal ini 
bermakna bahwa hampir seluruh responden menginginkan dirinya menjadi yang terbaik dengan melakukan yang terbaik juga.

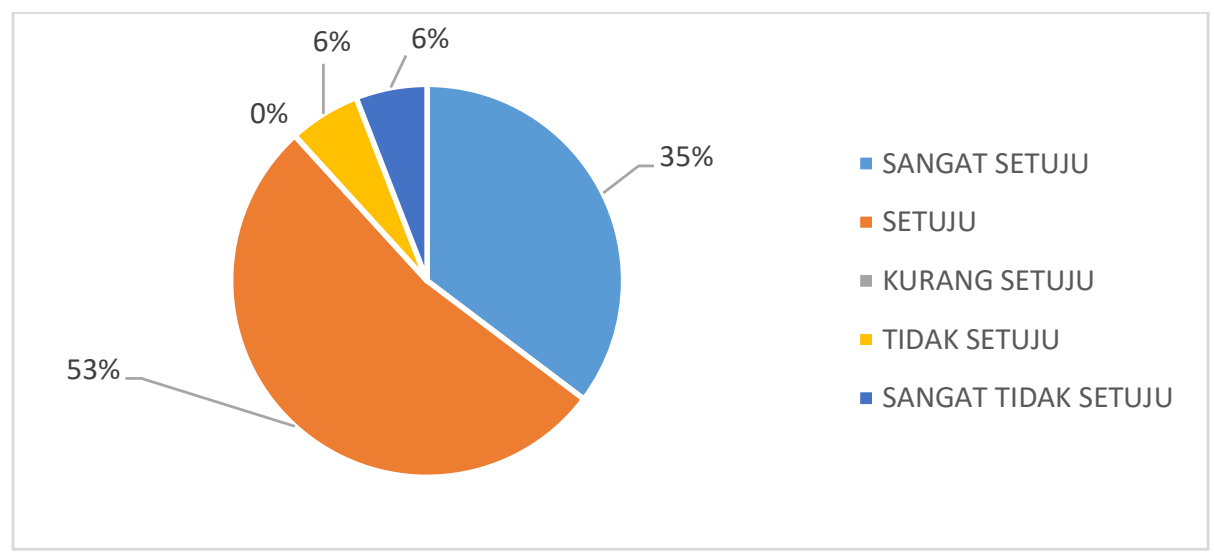

\section{Gambar 13. Ingin Menjadi yang Terbaik}

\section{Mengukur Etos Kerja Muslim Al-Mujahadah}

Sementara itu, berdasarkan Gambar 14, untuk pertanyaan rela bekerja meskipun di luar jam kerja untuk menyelesaikan pekerjaan terutama ketika mendekati batas waktu (deadline), sebanyak 29 \% orang tidak setuju dan di sisi lain, sebanyak $29 \%$ orang setuju dengan pertanyaan tersebut. Hal ini bermakna separuh dari responden rela bekerja meskipun di luar waktu kerja demi menyelesaikan tugas yang dipercayakan namun separuh lainnya justru kurang tidak setuju artinya tidak rela bekerja di luar jam kerja apapun alasannya, sekalipun untuk menyelesaikan pekerjaan.



Gambar 14. Rela Bekerja di Luar Jam Kerja

\section{Mengukur Etos Kerja Muslim Tanafus dan Ta'awun}


Pada pertanyaan mau menolong dengan senang hati ketika rekan ada yang kesulitan meskipun pekerjaan tersebut berat, dimana sebanyak $65 \%$ setuju bahwa mereka mau menolong. Hal tersebut bermakna bahwa sebagian besar sudah memiliki etos kerja muslim tanafus dan ta'awun (Gambar 15).

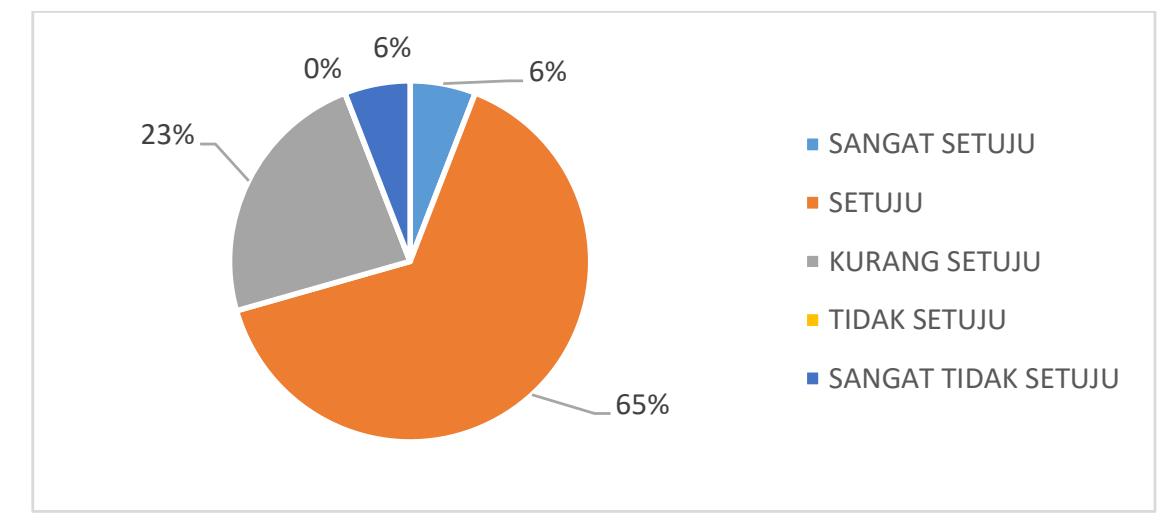

\section{Gambar 15. Mau Menolong}

\section{Mengukur Etos Kerja Muslim Mencermati Nilai Waktu}

Pada pertanyaan menghargai waktu, sebanyak 70 \% setuju bahwa mereka adalah orang yang sangat menghargai waktu sehingga tidak pernah terlambat dan mengerjakan pekerjaan dengan tepat waktu. Hal tersebut bermakna bahwa sebagian besar sudah mencermati nilai waktu karena sudah bekerja dengan memanfaatkan waktu dengan sebaik-baiknya (Gambar 16).

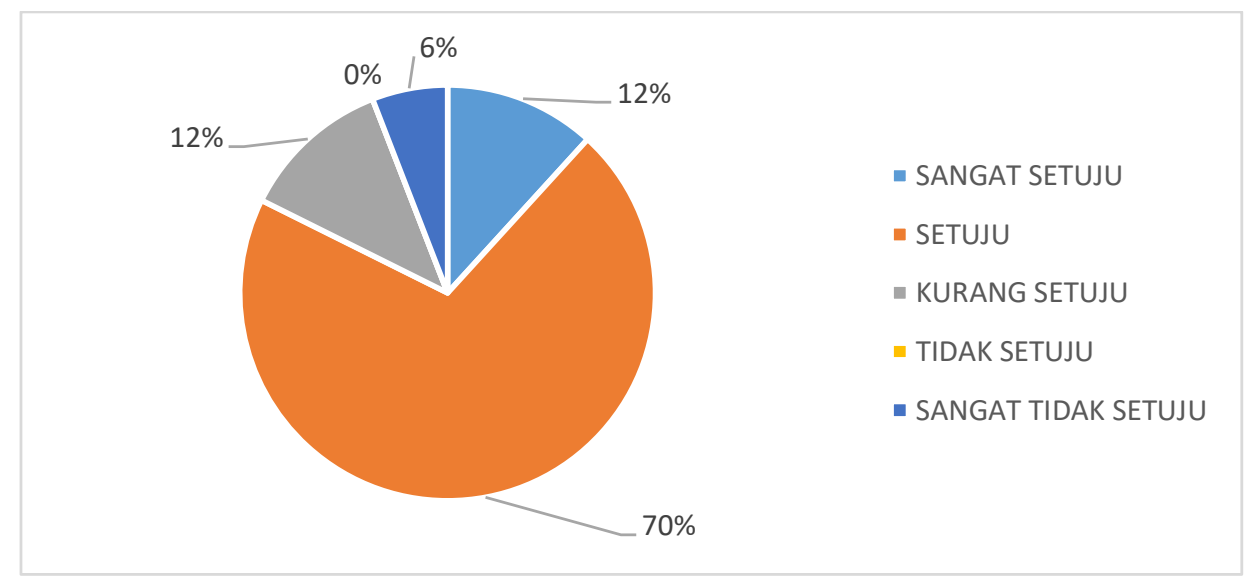

\section{Gambar 16. Menghargai Waktu}

Sementara itu, berdasarkan Gambar 17, untuk pertanyaan suka menunda-nunda pekerjaan, sebanyak $59 \%$ orang tidak setuju dan di sisi lain, sebanyak $29 \%$ orang bahkan sangat tidak setuju dengan pertanyaan tersebut. Hal ini bermakna separuh dari responden telah memiliki etos kerja muslim yaitu menghargai waktu. Karena mayoritas sepakat bahwa menundanunda pekerjaan bukanlah hal yang baik. 


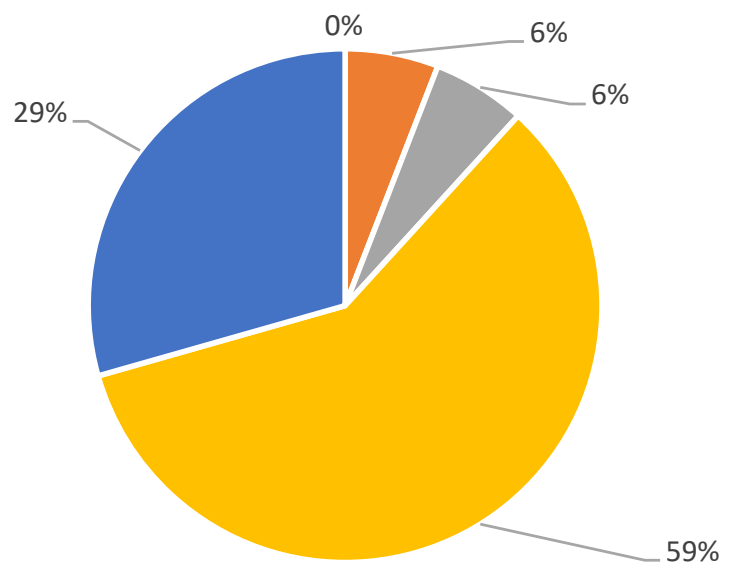

- SANGAT SETUJU

- SETUJU

- KURANG SETUJU

- TIDAK SETUJU

- SANGAT TIDAK SETUJu

Gambar 17. Menunda Pekerjaan

\section{KESIMPULAN}

Berdasarkan hasil penelitian maka ditarik beberapa kesimpulan bahwa etos kerja muslim di Fakultas Ekonomi dan Bisnis Islam IAIN Padangsidimpuan pada tenaga pengajar (dosen) dan tenaga administrasi sudah baik. Hal tersebut dapat dilihat dari hasil penelitian ini, dimana untuk etos kerja muslim al-shalah (baik dan manfaat), al-itqan (kemantapan dan perfectness), tanafus dan ta'awun (berkompetisi dan tolong-menolong) dan mencermati nilai waktu sudah dilakukan selama bekerja. Hanya saja untuk etos kerja muslim al-mujahadah (kerja keras dan optimal) masih kurang dalam sebagian diri responden.

\section{DAFTAR PUSTAKA}

Ali Sambas Muhidin dan Abdurrahman Maman. (2009). Analisis Korelasi, Regresi dan Jalur dalam Penelitian. Bandung: Pustaka Setia.

Dermawan, Wibisono. (2003). Riset Bisnis: Panduan bagi Praktisi dan Akademisi. Jakarta: Gramedia Pustaka Utama.

Didin, Hafidhuddin dan H. Tanjung. (2003). Manajemen Syariah dalam Praktik. Jakarta: Gema Insani.

Emzir. (2014). Metodologi Penelitian Kualitatif Analisis Data. Jakarta: Rajagrafindo Persada.

Gay and Airasia. (2000). Educational Research. Cambridge: Cambridge University Press.

Muhammad. (2008). Metodologi Penelitian Ekonomi Islam. Jakarta: Rajawali Pers. 
Schein, E.H. (2008). Organizational Culture and Leadership. San Francisco: Jossey-Bass.

Terry, George. (2005). Dasar-Dasar Manajemen. Jakarta: PT. Bumi Aksara.

Databoks Katadata. (2018). Jumlah Penduduk Indonesa Menurut Kelompok Umus. Diakses dari https://databoks.katadata.co.id/datapublish/2018/05/18/2018-jumlah-pendudukindonesia-mencapai-265-juta-jiwa, diakses 29 Agustus 2018 pukul 17.16 WIB.

Berita Online Thoughtco. (2018). Worlds Muslim Population. Diakses dari https://www.thoughtco.com/worlds-muslim-population-2004480, diakses 06 September 2018 pukul 17.04 WIB. 